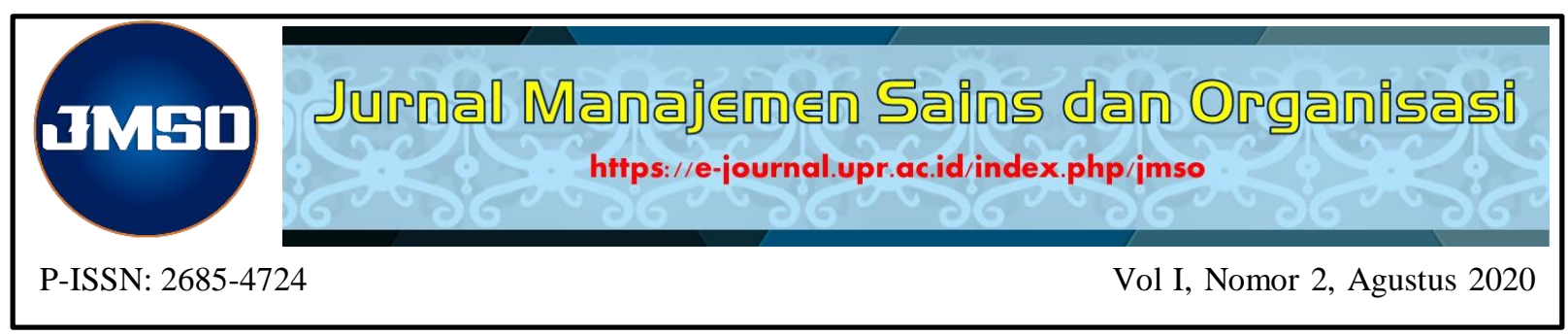

\title{
Pengaruh Rasio Keuangan Terhadap Pertumbuhan Laba Pada Perusahaan Telekomunikasi Yang Terdaftar Di Bursa Efek Indonesia
}

\author{
Maryeta ${ }^{1)}$ \\ Jurusan Manajemen, Fakultas Ekonomi dan Bisnis \\ Universitas Palangka Raya, Indonesia \\ Murie P. Kulu 2) \\ Jurusan Manajemen, Fakultas Ekonomi dan Bisnis \\ Universitas Palangka Raya, Indonesia \\ Deddy Rakhmad Hidayat ${ }^{3}$ \\ Jurusan Manajemen, Fakultas Ekonomi dan Bisnis \\ Universitas Palangka Raya, Indonesia \\ Email:maryetayeta5@gmailcom
}

\begin{abstract}
Abstrak
Tujuan - Penelitian ini bertujuan untuk menganalisis Pengaruh Rasio Keuangan Terhadap Pertumbuhan Laba pada Perusahaan Telekomunikasi yang terdaftar di Bursa Efek Indonesia.

Desain/Metodelogi/Pendekatan - Sampel dalam penelitian ini berjumlah 6 perusahaan yang dipilih menggunakan metode purposive sampling. Alat analisis yang digunakan adalah SPSS.

Temuan - Berdasarkan analisis yang telah dilakukan diperoleh hasil bahwa Current Ratio tidak berpengaruh terhadap pertumbuhan laba. Debt Ratio berpengaruh positif terhadap pertumbuhan laba. Total Assets Turnover tidak berpengaruh tehadap pertumbuhan laba. Return On Assets berpengaruh positif terhadap pertumbuhan laba. Price Earning Ratio tidak berpengaruh. terhadap pertumbuhan laba.
\end{abstract}

Kata kunci: current ratio, debt ratio, total assets turnover, return on assets, price earning ratio dan pertumbuhan laba.

\section{Quality of service and business image on satisfaction and its effect on tourist loyalty}

Purpose - The purpose of this study is to analyze the effect of financial ratios on profit growth in Indonesian Stock Exchange-listed telecommunications companies.

Design / Method / Approach - In this study, the sample included 6 companies using the method of purposive sampling. The method of research used in SPSS.

Findings - It is observed based on the analysis that has been performed that the present ratio does not affect

Keywords: current ratio, debt ratio, total asset turnover, return on assets, price earning ratio and profit growth

Maryeta, Murie P. Kulu, Deddy Rakhmad. Published in the Jurnal Manajemen sains dan Organsasi. Published by FEB UPR Publishing Limited. This article is published under the Creative Commons Attribution (CC BY 4.0) licence. Anyone may reproduce, distribute, translate and create derivative works of this article (for both commercial and non-commercial purposes), subject to full attribution to the original publication and authors. 


\section{PENDAHULUAN}

Bursa Efek Indonesia merupakan salah satu tempat transaksi perdagangan saham dari berbagai jenis perusahaan yang ada di Indonesia. Ada beberapa jenis perusahaan yang terdaftar di Bursa Efek Indonesia, yaitu perusahaan pertanian, pertambangan, industri dasar dan kimia, aneka industri, industri barang konsumsi, property, infrastruktur, keuangan, dan perdagangan jasa investasi. Perusahaan telekomunikasi adalah salah satu perusahaan yang ikut berperan dalam pasar modal. Untuk mencapai tujuannya, pengelolaan perusahaan harus dilakukan dengan sebaik mungkin agar dapat menjadi perusahaan yang mampu bersaing dengan perusahaan telekomunikasi yang lain. Wujud dari pengelolaan perusahaan yang baik dapat dilihat dari kinerja perusahaan. Kinerja perusahaan salah satunya dapat dinilai melalui pertumbuhan laba. Apabila kinerja perusahaan baik maka pertumbuhan laba meningkat, begitu juga sebaliknya apabila kinerja perusahaan tidak baik maka pertumbuhan laba akan menurun.

Tujuan perusahaan pada umumnya adalah memperoleh laba. Akan tetapi laba yang besar belum tentu memaksimalkan nilai perusahaan. Kemampuan menghasilkan laba yang maksimal pada suatu perusahaan sangat penting karena pada dasarnya pihakpihak yang berkepentingan, misalnya investor dan kreditor mengukur keberhasilan perusahaan berdasarkan kemampuan perusahaan yang terlihat dari kinerja manajemen dalam menghasilkan laba dimasa mendatang.

Menurut Suprihatmi (2006). Untuk dapat menilai kinerja perusahaan, maka pihak-pihak yang berkepentingan, perlu mengetahui kondisi keuangan perusahaan yang dapat diketahui dari laporan keuangan perusahaan. Bagi perusahaan yang Go Publik laporan keuangan bersifat terbuka yang berarti laporan keuangan perusahaan perusahaan tersebut telah dipublikasikan sehingga dapat dilihat dan dibaca oleh masyarakat umum dan juga para pemakai laporan keuangan baik intern maupun ekstern. Laporan keuangan akan menggambarkan kondisi dan perkembangan keuangan perusahaan, sehingga pihak internal maupun eksternal dapat memanfaatkan laporan perkembangan keuangan untuk kepentingan masing-masing. Bagi pihak internal informasi keuangan diperlukan untuk mengetahui keadaan perusahaan dan membantu dalam mengambil keputusan yang berkaitan dengan aktivitas operasi perusahaan, sedangkan bagi pihak eksternal informasi keuangan digunakan untuk menentukan posisi kedudukan perusahaan, pemberian kredit dan melakukan investasi.

Laporan keuangan merupakan salah satu sumber informasi penting bagi para pemakai laporan keuangan dalam rangka pengambilan keputusan ekonomi. Tetapi perlu disadari pula bahwa ternyata laporan keuangan juga mempunyai beberapa sifat dan keterbatasan, seperti misalnya bersifat historis. Tanpa mempermasalahkan bagaimana cermatnya suatu laporan keuangan disusun, semua laporan keuangan pada dasarnya merupakan dokumen historis dan statis. Informasi laporan keuangan yang dihasilkan dari data yang bersifat historis, membutuhkan teknik intepretasi yang bagus, supaya dapat menjelaskan kondisi perusahaan secara fundamental .

Interprestasi dan analisis laporan keuangan suatu perusahaan diperlukan adanya alat ukur tertentu. Ukuran yang sering digunakan untuk menganalisis laporan keuangan adalah rasio. Rasio merupakan alat ukur yang dinyatakan dalam arithmetical terms. Yang dapat digunakan untuk menjelaskan hubungan antara dua macam data finansiil.(Riyanto, 2001).

Analisis rasio merupakan suatu bentuk atau cara yang umum digunakan dalam 
menganalisis laporan finansial suatu perusahaan. Dengan menggunakan alat analisis berupa rasio ini akan dapat menjelaskan atau memberi gambaran kepada penganalisa tentang baik buruknya keadaan atau posisi keuangan suatu perusahaan. Penganalisa harus mampu untuk menyesuaikan faktor-faktor yang ada pada periode atau waktu ini dengan faktor-faktor dimasa yang akan datang yang mungkin akan mempengaruhi posisi keuangan atau hasil operasi perusahaan yang bersangkutan (Munawir, 2002).

Salah satu rasio keuangan yang digunakan untuk menentukan kinerja keuangan perusahaan dari sisi laba adalah profitabilitas. Menurut Harahap (2009), profitabilitas menggambarkan kemampuan perusahaan dalam mendapatkan laba selama periode tertentu. Apabila kemampuan suatu perusahaan dalam menghasilkan laba rendah maka penilaian terhadap rasio profitabilitas juga akan rendah dan hal ini akan mengakibatkan investor yang ingin menanamkan saham merasa ragu untuk melakukan investasi. Para kreditur juga akan memiliki keraguan untuk memberikan pinjaman kepada perusahaan tersebut, karena mereka ingin mendapatkan suatu jaminan bahwa perusahaan tempat mereka menanamkan modalnya akan mampu membayar bunga dan pinjaman pokok tepat pada waktunya. Demikian pula, sebaliknya apabila suatu perusahaan mempunyai kemampuan menghasilkan laba yang tinggi maka penilaian terhadap rasio profitabilitas juga akan tinggi dan hal ini membuat investor dan kreditur akan tertarik untuk menanamkan modalnya pada perusahaan tersebut.

Pertumbuhan laba, juga dapat diketahui berdasarkan tingkat efektivitas dari penggunaan asset perusahaan. Efisiensi dan efektivitas pengelolaan aktiva juga dapat ditunjukan dengan rasio efisiensi yang sering disebut juga dengan rasio aktivitas. Rasio aktivitas merupakan rasio yang digunakan untuk menunjukan sejauh mana efisiensi perusahaan didalam menggunakan aktiva yang dimilikinya untuk memperoleh penjualan. Semakin tinggi rasio ini menunjukan bahwa sumber daya atau aktiva yang dimiliknya telah dimanfaatkan secara optimal.

Untuk mengetahui keberhasilan operasional suatu perusahaan, maka perlu diadakan analisis terhadap laporan kuangan, dimana dalam menganalisis laporan keuangan menggunakan rasio keuangan, yang menggunakan variabel dependen yaitu pertumbuhan laba dimaksudkan untuk menguji apakah Debt to Equity Ratio, Net Profit Margin, dan Return on Equity berpengaruh terhadap pertumbuhan laba sehingga dapat diperoleh gambaran mengenai naik turunnya (fluktuasi) posisi keuangannya.

Hernawati (2007) melakukan penelitian didapat dari jurnal ekonomi yang berjudul "Analisis Pengaruh Efisiensi Modal Kerja, Likuiditas, dan Solvabilitas terhadap Profitabilitas yang dilakukan oleh mahasiswi Universitas Negeri Semarang tahun 2007.

Beberapa penelitian sebelumnya menganalisis pengaruh rasio keuangan terhadap pertumbuhan laba Rika Susanti (2017) menyatakan bahwa semua variabel yang digunakan tidak berpengaruh positif signifikan terhadap pertumbuhan laba. Hasil penelitian ini berbeda dengan penelitian yang dilakukan oleh Ira Ayu Pradani (2018) dimana hasil penelitian menunjukkan bahwa hanya return on assets yng berpengaruh terhadap pertumbuhan.

H1: Current Ratio berpengaruh signifikan terhadap pertumbuhan laba

Current ratio merupakan salah satu rasio likuiditas. Current ratio menunjukkan kemampuan perusahaan untuk melunasi utang jangka pendek dengan menggunakan asset lancar perusahaan. Fahmi (2013) mengemukakan bahwa jika perusahaan mampu 
menutup kewajiban lancarnya dengan baik, maka perusahaan dapat mengelola aktiva lancer yang dimilikinya dengan baik sehingga dapat memberikan pengaruh terhadap perolehan laba perusahaan. semakin tinggi rasio lancer, maka semmakin tinggi kemampuan perusahaan untuk menutupi kewajiban lancarnya. Semakin tinggi rasio lancer, maka perusahaan akan semakin likuid dan semakin mudah memperoleh pendanaan dari kreditor maupun investor untuk memperlancar kegiatan operasionalnya, sehingga laba juga dapat meningkat (Rachmawati \& Handayani, 2014). Dengan demikian, dapat disimpulkan bahwa Current Ratio berpengaruh positif terhadap pertumbuhan laba.

H2 : Debt Ratio bepengaruh signifikan terhadap pertumbuhan laba

Debt ratio adalah ratio yang menunjukkan persentase dana yang disediakan para pemegang saham kepada pemberi pinjaman pada perusahaan yang disediakan oleh pemegang saham. Dari perspektif kemampuan membayar kewajiban, semakin rendah rasio akan semakin bagus kemampuan perusahaan membayar kewajibannya (Darsono, 2005).

H3: Toral Assets Turnover berpengaruh signifikan terhdap pertumbuhan laba

Total Asset Turnover merupakan salah satu rasio aktivitas. TAT merupakan rasio yang mengukur kemampuan perusahaan untuk menciptakan penjualan dengan menggunakan seluruh aktiva yang dimilikinya. Rasio TAT yang tinggi menunjukkan tingkat keefisienan perusahaan dalam menggunakan seluruh aktiva untuk mendukung penjualan perusahaan. Semakin cepat perputaran aktiva dalam mendukung penjualan perusahaan maka pendapatan perusahaan akan semakin besar sehingga laba perusahaanpun meningkat (Rachmawati dan Handayani, 2014). Laba yang semakin tinggi mencerminkan kinerja perusahaan baik sehingga akan menarik investor untuk menanamkan modalnya pada perusahaan tersebut. Dengan demikian, dapat disimpulkan bahwa Total Asset Turnover berpengaruh positif terhadap pertumbuhan laba.

H4: Return On Assets berpengaruh signifikan terhadap pertumbuhan laba

ROA merupakan salah satu rasio profitabilitas. ROA merupakan perbandingan antara laba bersih dengan asset perusahaan. ROA menunjukkan seberapa besar keuntungan atau laba bersih yang diperoleh dari asset perusahaan. Menurut Mubarok (2016) ROA yang positif menunjukkan bahwa dari total aktiva yang dipergunakan operasi perusahaan mampu memberikan laba perusahaan. Sebaliknya jika ROA negatif menunjukkan total aktiva yang dipergunakan tidak memberikan keuntungan. Sehingga ROA yang tinggi menunjukkan tingkat keefisienan penggunaan asset perusahaan untuk menghasilkan laba perusahaan. Semakin efisien perusahaan berarti semakin baik kinerja perusahaan. Dengan demikian, dapat disimpulkan bahwa Return On Asset berpengaruh positif terhadap pertumbuhan laba.

H5 : Price Eaning Ratio berpengaruh signifikan terhadap pertumbuhan laba

Price Earning Ratio adalah suatu rasio yang mengukur seberapa besar perbandingan antara harga saham perusahaan dengan keuntungan yang akan diperoleh oleh para pemegang saham.

H6 : Current ratio, debt ratio, total assets turnover, return on assets dan price earning 
ratio berpengaruh signifikan terhadap pertumbuhan laba.

\section{Motodelogi penelitian}

Penelitian ini merupakan penelitian deskripsif-kuantitatif. Sumber data yang digunakan untuk penelitian ini diperoleh dari situs resmi Bursa Efek Indonesia (BEI) yaitu www.idx.ci.id. Sampel dalam penelitian ini berjumlah 6 perusahaan yang dipilih dengan purposive sampling.

Variabel dan indikator yang digunakan dalam penelitian ini dapat dilihat dalam tabel berikut :

Tabel 1. Indentifikasi Variabel

\begin{tabular}{clc}
\hline Variabel & \multicolumn{1}{c}{ Definisi } & Indikator \\
\hline & Rasio likuiditas adalah rasio yang menunjukkan & \\
& kemampuan perusahaan dalam memenuhi & \\
& kewajiban atau membayar utang jangka pendeknya. & \\
& Rasio inilah yang dapat digunakan untuk mengukur & \\
Rasio Likuiditas (X1) & seberapa llikuidnya suatu perusahaan. Jika & Current Ratio (CR) \\
& perusahaan mampu memenuhi berarti perusahaan & \\
& tersebut likuid, sedangkan jika perusahaan tidak \\
& mampu memenuhi kewajibannya berarti & \\
perusahaan kewajibannya tersebut ilikuid. & \\
\hline
\end{tabular}

Rasio solvabilitas atau leverage adalah rasio untuk menilai kemampuan perusahaan dalam melunasi semua kewajibannya baik jangka pendek maupun

Rasio Solvabilitas (X2) jangka panjang dengan jaminan aktiva atau kekayaan yang dimiliki perusahaan hingga

Debt Ratio (DR) perusahaan tutup atau dilikuidasi.

\begin{tabular}{|c|c|c|}
\hline Rasio Aktivitas (X3) & $\begin{array}{l}\text { Rasio Aktivitas adalah rasio yang menggambarkan } \\
\text { aktivitas yang dilakukan perusahaan dalam } \\
\text { menjalankan operasinya baik dalam kegiatan } \\
\text { penjualan, pembelian, dan kegiatan lainnya. }\end{array}$ & Total Assets Turnover (TAT) \\
\hline $\begin{array}{l}\text { Rasio Profitabilitas } \\
\text { (X4) }\end{array}$ & $\begin{array}{l}\text { Profitabilitas adalah rasio yang digunakan untuk } \\
\text { mengukur kemampuan perusahaan menghasilkan } \\
\text { keuntungan pada tingkat penjualan, asset dan } \\
\text { modal saham tertentu. }\end{array}$ & Return On Assets (ROA) \\
\hline Rasio Pasar (X5) & $\begin{array}{l}\text { Rasio pasar yaitu rasio yang mengukur harga pasar } \\
\text { relatif terhadap nilai buku. Sudut pandang rasio ini } \\
\text { lebih banyak berdasar pada sudut investor atau } \\
\text { calon investor, meskipun pihak manajemen juga } \\
\text { berkepentingan terhadap rasio-rasio ini }\end{array}$ & Price Earning Ratio (PER) \\
\hline Pertumbuhan Laba (Y) & $\begin{array}{l}\text { pertumbuhan laba adalah rasio yangmenunjukkan } \\
\text { kemampuan perusahaan meningkatkan laba bersih } \\
\text { dibanding tahun sebelumnya. }\end{array}$ & Pertumbuhan Laba \\
\hline
\end{tabular}

Metode analisis data yang dilakukan dalam penelitian ini adalah dengan menggunakan software SPSS. 


\section{HASIL DAN PEMBAHASAN}

Tabel 1. Statistik Deskriptif

\begin{tabular}{lrrrrr}
\hline Variabel & N & Minimum & Maximum & Mean & Std. Deviation \\
\hline CR & 25 & 0,005 & 1,352 & 0,516 & 0,381 \\
\hline DR & 25 & 0,388 & 21,270 & 2,892 & 5,839 \\
\hline TAT & 25 & 0,003 & 0,647 & 0,345 & 0,205 \\
\hline ROA & 25 & $-3,583$ & 0,164 & $-0,312$ & 0,842 \\
\hline PER & 25 & $-1228,950$ & 84,306 & $-46,574$ & 249,645 \\
\hline PL & 25 & $-34,167$ & 3,591 & $-0,856$ & 7,140 \\
\hline
\end{tabular}

Sumber: Hasil analisis SPSS

Berdasarkan hasil uji deskriptif pada tabel 4.1 dapat dijelaskan hasilnya sebagai berikut: Current Ratio (CR) memiliki nilai minimum sebesar 0,005, nilai maksimum sebesar 1,352, nilai rata-rata sebesar 0,516 dan standar deviasi sebesar 0,381. Nilai standar deviasi yang lebih kecil dari nilai rata-rata menunjukkan kesenjangan variabel Current Ratio kecil. Semakin kecil standar deviasi, maka semakin rendah penyebaran data pengamatan dan variabelitasnya.

Debt Ratio (DR) memiliki nilai minimum sebesar 0,388, nilai maksimum sebesar 21,270, nilai rata-rata sebesar 2,892 dan standar deviasi sebesar 5,839. Nilai standar deviasi yang lebih besar dari nilai rata-rata menunjukkan kesenjangan variabel Debt Ratio besar. Semakin besar standar deviasi, maka semakin menyebar data pengamatan dan memiliki kecenderungan setiap data berbeda atau memiliki variabelitas tinggi.

Total Assets Turnover (TAT) memiliki nilai minimum sebesar 0,003, nilai maksimum sebesar 0,647, nilai rata-rata sebesar 0,345 dan standar deviasi sebesar 0,205. Nilai standar deviasi yang lebih kecil dari nilai rata-rata menunjukkan kesenjangan variabel Total Assets Turnover kecil. Semakin kecil standar deviasi, maka semakin rendah penyebaran data pengamatan dan variabelitasnya.

Return On Assets (ROA) memiliki nilai minimum sebesar -3,583, nilai maksimum sebesar 0,164, nilai rata-rata sebesar $-3,012$ dan standar deviasi sebesar 0,842. Nilai standar deviasi yang lebih besar dari nilai rata-rata menunjukkan kesenjangan variabel Return On Assets besar. Semakin besar standar deviasi, maka semakin menyebar data pengamatan dan memiliki kecenderungan setiap data berbeda atau memiliki variabelitas tinggi.

Price Earning Ratio (PER) memiliki nilai minimum sebesar -1228,950, nilai maksimum sebesar 84,306, nilai rata-rata sebesar -46,574 dan standar deviasi sebesar 249.645. Nilai standar deviasi yang lebih besar dari nilai rata-rata menunjukkan kesenjangan variabel Price Earning Ratio besar. Semakin besar standar deviasi, maka semakin menyebar data pengamatan dan memiliki kecenderungan setiap data berbeda atau memiliki variabelitas tinggi.

Pertumbuhan Laba (PL) memiliki nilai minimum sebesar -34,167, nilai maksimum sebesar 3,591, nilai rata-rata sebesar $-0,856$ dan standar deviasi sebesar 7,140. Nilai standar deviasi yang lebih besar dari nilai rata-rata menunjukkan kesenjangan variabel 
Price Earning Ratio besar. Semakin besar standar deviasi, maka semakin menyebar data pengamatan dan memiliki kecenderungan setiap data berbeda atau memiliki variabelitas tinggi.

Tabel 2. Pengujian Hipotesis

\begin{tabular}{crrr}
\hline Variabel & T & Sig & \multicolumn{1}{c}{ Keterangan } \\
\hline Current Ratio & $-0,070$ & 0,945 & Tidak Signifikan \\
Debt Ratio & 3,258 & 0,004 & Signifikan \\
Total Assets Turnover & $-1,438$ & 0,167 & Tidak Signifikan \\
Return On Assets & 2,952 & 0,008 & Signifikan \\
Price Earning Ratio & $-0,941$ & 0,358 & Tidak Signifikan \\
\hline
\end{tabular}

Sumber: Hasil analisis SPSS

Berdasarkan tabel 2. diatas variabel variabel Current Ratio memiliki thitung sebesar -0,070 ini lebih kecil dari nilai tabel yang sebesar 2,0902 dan pada nilai signifikansi yaitu sebesar 0,945 > 0,05, sehingga dapat disimpulkan bahwa Current Ratio tidak berpengaruh terhadap pertumbuhan laba pada perusahaan Telekomunikasi yang terdaftar di Bursa Efek Indonesia. Variabel Debt Ratio memiliki thitung sebesar 3,258 ini lebih besar dari nilai $t_{\text {tabel }}$ yang sebesar 2,0902 dan pada nilai signifikansi yaitu sebesar 0,004 $<0,05$, sehingga dapat disimpulkan bahwa Debt Ratio berpengaruh signifikan terhadap pertumbuhan laba pada perusahaan Telekomunikasi yang terdaftar di Bursa Efek Indonesia. Variabel Total Assets Turnover memiliki thitung sebesar -1,438 ini lebih kecil dari nilai tabel yang sebesar 2,0902 dan pada nilai signifikansi yaitu sebesar 0,167 >0,05, sehingga dapat disimpulkan bahwa Total Assets Turnover tidak berpengaruh terhadap pertumbuhan laba pada perusahaan Telekomunikasi yang terdaftar di Bursa Efek Indonesia.Sedangkan variabel variabel Return On Assets memiliki thitung sebesar 2,952 ini lebih besar dari nilai tabel yang sebesar 2,0902 dan pada nilai signifikansi yaitu sebesar $0,008<0,05$, sehingga dapat disimpulkan bahwa Return On Assets berpengaruh positif terhadap pertumbuhan laba pada perusahaan Telekomunikasi yang terdaftar di Bursa Efek Indonesia. Da variabel Price Earning Ratio memiliki thitung sebesar -0,941 ini lebih kecil dari nilai $t_{\text {tabel }}$ yang sebesar 2,0902 dan pada nilai signifikansi yaitu sebesar 0,358 > 0,05, sehingga dapat disimpulkan bahwa Price Earning Ratio tidak berpengaruh terhadap pertumbuhan laba pada perusahaan Telekomunikasi yang terdaftar di Bursa Efek Indonesia.

Sedangkan pengujian dengan menggunakan F Hitung ditemukan bahwa nilai $F_{\text {hitung }}$ sebesar 4,690 yang berarti lebih besar dari $F_{\text {tabel }}$ yaitu sebesar 2,74 dan nilai signifikansi dapat dilihat yaitu sebesar 0,006 yang lebih kecil dari 0,05. Maka dapat disimpulkan bahwa variabel bebas yang terdiri dari Current Ratio, Debt Ratio, Total Assets Turnover, Return On Assets dan Price Earning Ratio secara bersama-sama (simultan) berpengaruh terhadap pertumbuhan Laba. 


\section{SIMPULAN}

Berdasarkan hasil pengujian hipotesis dan pembahasan yang telah dikemukakan sebelumnya, maka diperoleh kesimpulan bahwa:

Secara parsial penelitian ini menunjukkan hanya debt ratio dan return on assets yang berpengaruh secara signifikan terhadap pertumbuhan laba pada perusahaan telekomunikasi yang terdaftar di BEI. Sedangkan variabel current ratio, total assets turnover dan price earning tidak memiliki pengaruh terhadap pertumbuhan laba. Secara simultan, hasil penelitian ini menujukkan bahwa semua variabel (current ratio, debt ratio, total assets turnover, return on assets dan price earning ratio) berpengaruh terhadap pertumbuhan laba pada perusahaan telekomunikasi yang terdaftar di BEI.

Rasio keuangan yang terdiri dari current ratio, debt ratio, total assets turnover, return on assets dan price earning ratio mempunyai kontribusi sebesar $43,5 \%$ dalam mempengaruhi laba, sedangkan selebihnya sebesar 56,5\% dipegaruhi oleh variabel lainnya yang tidak diteliti pada penelitian ini.

\section{Referensi}

Angkoso. (2006). Pengaruh Rasio Keuangan Terhadap Pertumbuhan Laba Pada Perusahaan Industri Barang Konsumsi yang Terdaftar di BEI. Skripsi, Fakultas Ekonomi, Universitas Sumatera Utara.

Ghozali, Imam.(2016). Aplikasi Analisis Multivariate Dengan Program IBM SPSS.

Harahap, S.S. (2015). Analisis Laporan Keuangan.. Jakarta: PT RajaGrafindo Persada.

Ika Wahyu Nurrini (2018). Kemampuan Rasio Keuangan, Inflasi dan Gross Doestic Product (GDP) Dalam Memprediksi Pertumbuhan Laba Perusahaan (Studi pada Perusahaan Jasa yang Terdaftar di Bursa Efek Indonesia Periode 2014-2016). Skripsi. Univeritas Negeri Yogyakarta.

Ima Andriyani. 2015. "Pengaruh Rasio Keuangan Terhadap Pertumbuhan Laba Pada Perusahaan Pertambangan Yang Terdaftar Di Bursa Efek Indonesia". Skripsi, Jurnal Manajemen dan Bisnis Sriwijaya Vol.13 No.3.

Kasmir.(2016). Analisa Laporan Keuangan. Jakarta:PT RajaGrafindo Persada.

Munawir, S. (2014).Analisa Laporan Keuangan. Edisi Keempat. Yogyakarta: Liberty.

Oktanto dan Nuryatno. (2014). Pengaruh Rasio Keuangan Terhadap Pertumbuhan Laba Pada Perusahaan Manufaktur Yang Terdaftar Di Bursa Efek Indonesia (BEI) 20082011. Volume.1 Nomor. 1 Februari 2014, 60-77.

Pengertian laporan arus kas. Tersedia di https://www.temukanpengertian.com/2016/02/pengertian-laporan-arus-kas.html diakses pada tanggal 6 juni 2019.

Pengertian laporan laba rugi. Tersedia di https://www.beecloud.id/pengertian-fungsidan-contoh-laporan-laba-rugi-akuntansi/ diakses pada tanggal 6 juni 2019.

Pengertian neraca. Tersedia di https://www.temukanpengertian.com/2016/01/pengertian-neraca.html diakses pada tanggal 6 juni 2019.

Pengertian rasio aktivitas. Tersedia di https://dosenakuntansi.com/rasio-aktivitas diakses pada tanggal 6 juni 2019.

Pengertian rasio profitabilitas. Tersedia di https://dosenakuntansi.com/rasio- 
profitabilitas diakses pada tanggal 6 juni 2019.

Pengertian rasio solvabilitas. Tersedia di

https://ilmumanajemenindustri.com/pengertian-rasio-solvabilitas-rasio-leveragejenisnya/ diakses pada tanggal 6 juni 2019.

Subramanyam dan Wild. (2014:25). Analisis Laporan Keuangan. Jakarta: Salemba Empat.

Suprihatmi. (2006). Pengaruh Rasio Keuangan Terhadap Kemampuan Memprediksi Perubahan Laba pada Perusahaan-Perusahaan Manufaktur yang Terdaftar di PT Bursa Efek Jakarta. Skripsi, Suarakarta: Universitas Slamet Riyadi. http://granuuviq.blogspot.com/2013/10/profil-pt-indosat-tbk.html 